British Journal of Nutrition (2022), 128, 1730-1737

doi:10.1017/S0007114521004669

(C) The Author(s), 2021. Published by Cambridge University Press on behalf of The Nutrition Society. This is an Open Access article, distributed under the terms of the Creative Commons Attribution licence (https://creativecommons.org/licenses/by/4.0/), which permits unrestricted re-use, distribution, and reproduction in any medium, provided the original work is properly cited.

\title{
Divergent effects of sex and calcium/vitamin D supplementation on serum magnesium and markers of bone structure and function during initial military training
}

\author{
Stephen R. Hennigar ${ }^{1,2,3 *}$, Alyssa M. Kelley ${ }^{2,3}$, Anna T. Nakayama ${ }^{3,4}$, Bradley J. Anderson ${ }^{2,3}$, \\ James P. McClung ${ }^{2}$ and Erin Gaffney-Stomberg ${ }^{4}$ \\ ${ }^{1}$ Florida State University, Department of Nutrition and Integrative Physiology, Tallahassee, FL, USA \\ ${ }^{2}$ US Army Research Institute of Environmental Medicine (USARIEM), Military Nutrition Division, Natick, MA, USA \\ ${ }^{3}$ Oak Ridge Institute for Science and Education, Belcamp, MD, USA \\ ${ }^{4}$ USARIEM, Military Performance Division, Natick, MA, USA
}

(Submitted 8 July 2021 - Final revision received 15 October 2021 - Accepted 9 November 2021 - First published online 24 November 2021)

\section{Abstract}

Maintaining Mg status may be important for military recruits, a population that experiences high rates of stress fracture during initial military training (IMT). The objectives of this secondary analysis were to (1) compare dietary Mg intake and serum Mg in female and male recruits pre- and post-IMT, (2) determine whether serum Mg was related to parameters of bone health pre-IMT, and (3) whether Ca and vitamin D supplementation (Ca/vitamin D) during IMT modified serum Mg. Females ( $n$ 62) and males ( $n 51)$ consumed $2000 \mathrm{mg}$ of Ca and $25 \mu \mathrm{g}$ of vitamin $\mathrm{D} / \mathrm{d}$ or placebo during IMT (12 weeks). Dietary Mg intakes were estimated using FFQ, serum Mg was assessed and peripheral quantitative computed tomography was performed on the tibia. Dietary $\mathrm{Mg}$ intakes for females and males pre-IMT were below the estimated average requirement and did not change with training. Serum Mg increased during IMT in females $(0.06 \pm 0.08 \mathrm{mmol} / \mathrm{l})$ compared with males $(-0.02 \pm 0.10 \mathrm{mmol} / \mathrm{l} ; P<0.001)$ and in those consuming Ca/vitamin D $(0.05 \pm 0.09 \mathrm{mmol} / \mathrm{l})$ compared with placebo $(0.001 \pm 0.11 \mathrm{mmol} / \mathrm{l}$; $P=0.015)$. In females, serum Mg was associated with total bone mineral content (BMC, $\beta=0.367, P=0.004)$ and robustness $(\beta=0.393$, $P=0.006)$ at the distal $4 \%$ site, stress-strain index of the polaris axis $(\beta=0.334, P=0.009)$ and robustness $(\beta=0.420, P=0.004)$ at the $14 \%$ diaphyseal site, and BMC $(\beta=0.309, P=0.009)$ and stress-strain index of the polaris axis $(\beta=0.314, P=0.006)$ at the $66 \%$ diaphyseal site pre-IMT. No significant relationships between serum Mg and bone measures were observed in males. Findings suggest that serum Mg may be modulated by $\mathrm{Ca} /$ vitamin $\mathrm{D}$ intake and may impact tibial bone health during training in female military recruits.

Key words: Serum magnesium: Magnesium status: Reference interval: Dietary reference intakes

$\mathrm{Mg}$ is an essential mineral that imparts critical structural and functional roles in the body. Approximately 50-60\% of total body Mg is found in bone ${ }^{(1)}$ either conjugated to hydroxyapatite crystals or on the bone surface and is involved in bone cell function and hydroxyapatite crystal formation. $\mathrm{Mg}$ on the bone surface is thought to be an exchangeable $\mathrm{Mg}$ pool to help maintain serum $\mathrm{Mg}$ concentrations ${ }^{(2)}$. A small amount of $\mathrm{Mg}(1 \%)$ is found extracellularly and the remaining is primarily found in soft tissue, mainly skeletal muscle ${ }^{(1)}$. Mg in this capacity is bound to phospholipids of cell membranes or associated with enzymes where it assists with membrane stabilisation or as a cofactor for enzymatic reactions, respectively.
In 2015, the Dietary Guidelines Advisory Committee found that approximately half of all Americans, and as many as $87 \%$ of females aged 14-18 years were below the Estimated Average Requirement (EAR) for $\mathrm{Mg}(300 \mathrm{mg} / \mathrm{d})$ and characterised $\mathrm{Mg}$ as a shortfall nutrient ${ }^{(3)}$. Currently, serum $\mathrm{Mg}$ concentration is used to assess $\mathrm{Mg}$ status of an individual with a reference interval of $0.75-0.95 \mathrm{mmol} / \mathrm{l}^{(4)}$; however, there is debate as to whether to increase the lower cut-off to $0.85 \mathrm{mmol} / \mathrm{l}^{(5)}$. Serum $\mathrm{Mg}$ concentrations within the current clinical cut-off for $\mathrm{Mg}$ deficiency (i.e. subclinical or chronic latent $\mathrm{Mg}$ deficiency) have been related to increased risk for many chronic diseases, including osteoporosis ${ }^{(5,6)}$. Epidemiological studies

Abbreviations: BMC, bone mineral content; EAR, Etimated Average Requirement; IMT, initial military training; PTH, parathyroid hormone; TRAP5b, tartrateresistant acid phosphatase $5 \mathrm{~b}$

* Corresponding author: Stephen R. Hennigar, email shennigar@fsu.edu 
have reported a positive association between dietary $\mathrm{Mg}$ intake and bone mineral density ${ }^{(7,8)}$, and studies in rodents have documented direct effects of even marginal $\mathrm{Mg}$ restriction on bone health ${ }^{(9-13)}$. A meta-analysis found that low serum Mg concentrations were a risk factor for osteoporosis in postmenopausal women ${ }^{(1)}$.

Skeletal stress fractures are common during initial military training (IMT) but disproportionately affect female (8-21\%) as compared with male $(2-5 \%)$ recruits $^{(14)}$. In fact, female sex is the most commonly identified risk factor for stress fracture ${ }^{(14)}$. Stress fractures are the result of repetitive mechanical deformation of the bone resulting in fatigue damage. During IMT, recruits experience unaccustomed, repetitive physical activity such as standing in formation, marching while carrying loads and running or sprinting. Mg requirements increase in individuals who routinely engage in strenuous physical activity, as $\mathrm{Mg}$ is involved in processes that affect muscle function such as energy production, nucleic acid and protein synthesis, muscle contraction, and oxygen uptake ${ }^{(15,16)}$. Moreover, physical activity may result in increased $\mathrm{Mg}$ excretion through sweat and urine ${ }^{(16)}$. Coupled with low dietary $\mathrm{Mg}$ intakes, these data indicate that military recruits may be vulnerable to chronic latent $\mathrm{Mg}$ deficiency and its associated symptoms, particularly detriments in bone health.

The primary objectives of this retrospective analysis of a randomised, double-blind, placebo-controlled trial were to (1) characterise dietary $\mathrm{Mg}$ intake and serum $\mathrm{Mg}$ concentrations in female and male recruits pre- and post-IMT and (2) determine whether serum $\mathrm{Mg}$ was associated with parameters of bone health in female and male recruits starting military training. The current analysis was conducted using a subset of participants enrolled in the previously published study which examined the effects of dietary $\mathrm{Ca} /$ vitamin $\mathrm{D}$ intake on bone health during military training ${ }^{(17)}$. Previous studies have demonstrated direct and indirect effects of vitamin D on intestinal Mg absorption $^{(18)}$. Thus, a secondary objective was to determine whether $\mathrm{Ca}$ and vitamin $\mathrm{D}$ supplementation $(\mathrm{Ca} /$ vitamin $\mathrm{D})$ during training modified serum $\mathrm{Mg}$.

\section{Methods}

\section{Participants}

This was a secondary analysis of a study that examined the effects of $\mathrm{Ca}$ /vitamin D supplemention on bone health in recruits undergoing United States Marine Corps IMT ${ }^{(17)}$. The study conformed to the principles of the Declaration of Helsinki and was approved by the Institutional Review Board at the US Army Research Institute of Environmental Medicine and registered at www.clinicaltrials.gov as NCT02636348. A total of 113 participants (females, $n$ 62; males, $n$ 51) who completed Marine Corps Basic Combat Training at Parris Island, $\mathrm{SC}\left(32^{\circ} \mathrm{N}\right.$ latitude), had serum available, and reported plausible energy intake in their FFQ (see dietary intake below) were used for this analysis.

\section{Intervention}

Participants were block randomised by race and sex to one of two intervention groups: placebo or $2000 \mathrm{mg}$ of $\mathrm{Ca}$ and
$25 \mu \mathrm{g}$ of vitamin D per d. These concentrations of Ca and vitamin $\mathrm{D}$ have been demonstrated to reduce stress fracture incidence in female Navy recruits provided capsules daily throughout training ${ }^{(19)}$. The current study expanded upon earlier findings by including both males and females undergoing training during two different seasons and evaluated effects of supplementation on circulating measures of bone health as well as imaging. Participants were assigned to receive food bars fortified with or without $\mathrm{Ca} /$ vitamin $\mathrm{D}$. Ca was added to the bars in the form of calcium carbonate and vitamin $\mathrm{D}$ was added as $\mathrm{D}_{3}$. A composite of five placebo and $\mathrm{Ca}$ /vitamin $\mathrm{D}$ bars were sent to Covance Laboratories (Madison, WI) for Ca, vitamin D and $\mathrm{Mg}$ analysis by ICP Emission Spectrometry. Placebo bars contained $20 \mathrm{mg}$ of $\mathrm{Ca},<0.02 \mu \mathrm{g}$ of vitamin $\mathrm{D}$, and $23 \mathrm{mg}$ of $\mathrm{Mg}$ and $\mathrm{Ca} /$ vitamin $\mathrm{D}$ bars contained $1032 \mathrm{mg}$ of $\mathrm{Ca}, 13.7 \mu \mathrm{g}$ of vitamin $\mathrm{D}$, and $26 \mathrm{mg}$ of $\mathrm{Mg}$. The placebo and $\mathrm{Ca} /$ vitamin $\mathrm{D}$ bars were identical in taste and appearance and conformed to all ration standards for safety and stability. Bars were consumed between meals (two times/d). Compliance was $98.3 \pm 2.5 \%$ in the placebo group and $95.7 \pm 8.5 \%$ in the $\mathrm{Ca} /$ vitamin $\mathrm{D}$ group.

\section{Military training}

Marine Corps Basic Combat Training consists of 12 weeks of physical and military-specific training. Physical requirements include aerobic activity such as foot marching with weighted packs, obstacle courses, distance running, and sprinting, and muscle strength training and callisthenic exercises. Recruits consume three self-selected meals/d in a dining facility during training and are not permitted to consume snacks (aside from the study intervention) or dietary supplements.

\section{Anthropometrics}

All anthropometric measures were determined pre- and postIMT, with the exception of height, which was measured at baseline to the nearest $0 \cdot 1 \mathrm{~cm}$ using a stadiometer (Creative Health Products). Weight was determined to the nearest $0 \cdot 1 \mathrm{~kg}$ on a calibrated digital scale (Belfour Scales) and BMI was calculated as body weight $(\mathrm{kg}) /$ height $(\mathrm{m})^{2}$. Skin fold thickness was measured at the tricep, suprailiac, and abdomen for women and tricep, suscapula, and chest for men. Measurements were made in duplicate to the nearest $\mathrm{mm}$. A third measurement was taken if the measurements differed by more than $2 \mathrm{~mm}$. Body fat percentage was estimated using sex-specific three-site skinfold Jackson-Pollock equations ${ }^{(20,21)}$.

\section{Dietary intake}

Pre- and post-IMT dietary intakes were estimated using a selfadministered validated FFQ (Block 2014 FFQ; NutritionQuest) under the supervision of Registered Dietitians. Pre-IMT questionnaires were answered relative to how the recruits ate for the 6 months prior to IMT, and post-IMT questionnaires were answered relative to how the recruits ate during the 12 weeks of IMT as previously reported ${ }^{(22)}$. Nutrient intake data were excluded from the analysis if energy intake was 
implausible $(<300$ or $>4500$ kcals for females; $<800$ or $>5000 \mathrm{kcal}$ for males) ${ }^{(23)}$.

\section{Blood collection and circulating biomarkers}

Fasting blood samples were collected by antecubital venepuncture into vacuum tubes (Vacutainer; Becton Dickinson). Serum $\mathrm{Mg}$ was measured using a colorimetric kit (BioVision, Inc.). Intact parathyroid hormone (PTH) was measured by immunoassay (Siemens Immulite 2000). Ionised Ca (iCa) was measured using a handheld iSTAT $^{\circledR}$ System point-of-care device and Chem8 + Cartridges (Abbott Laboratories). 25-hydroxyvitamin $\mathrm{D}$ and 1,25-dihydroxyvitamin $\mathrm{D}$ were determined by RIA (DiaSorin Inc.). Procollagen type 1 N-terminal propeptide (P1NP, MyBioSource), c-telopeptide cross-links of type 1 collagen (CTX, Immunodiagnostic Systems), tartrate-resistant acid phosphatase 5b (TRAP5b, Quidel) and bonespecific alkaline phosphatase (BAP, Quidel) were analysed by ELISA.

\section{Peripheral quantitative computed tomography}

Pre- and post-IMT peripheral quantitative computed tomography scans of the tibia were performed using the Stratec XCT-2000 or -3000 (Stratec Medizintechnik GmbH) as described previously ${ }^{(24)}$. Briefly, tibia length was measured on the non-dominant leg from the bottom of the medial malleolus to the tibial plateau. Scans of the 4, 14 and $66 \%$ sites of the total length of the tibia were taken to represent predominantly trabecular bone at the distal metaphysis ( $4 \%$ ) and cortical bone at the diaphyseal site (14 and $66 \%$ ). The following parameters were analysed at the metaphyseal site: volumetric bone mineral density $\left(\mathrm{mg} / \mathrm{cm}^{3}\right)$, total bone mineral content (BMC, $\mathrm{mg} / \mathrm{mm}$ ) and total bone strength index, an estimate of axial compression strength, was calculated as the product of total bone crosssectional area and the total density squared. At the diaphyseal sites, the following parameters were analysed: cortical volumetric bone mineral density, cortical BMC and stress-strain index of the polar axis $\left(\mathrm{mm}^{3}\right)$, an estimate of diaphyseal torsional strength was determined and robustness was calculated as total cross-sectional area $\left(\mathrm{mm}^{2}\right)$ divided by tibia length (mm) at the 4 and $14 \%$ sites as described previously ${ }^{(25-27)}$. Image processing was performed using the Stratec software package (version 6.2).

\section{Statistical analyses}

Data are reported as means and standard deviations. Baseline differences between females and males were determined using unpaired Student's $t$ tests. Two-way ANOVA was used to compare sex, intervention group and sex-by-intervention group interaction. Change scores were calculated by subtracting prefrom post-IMT values. Univariate and multiple linear regression models were used to examine the relationship between serum $\mathrm{Mg}$ concentrations and dietary $\mathrm{Mg}$ intakes or parameters of bone health. For dietary Mg intakes, univariate and multiple regression models adjusting for energy intake and accounting for age, race and BMI were used. For bone health, univariate and multiple regression models accounting for age, race, height, weight and intervention (model 1) and iCa (model 2) were used. Significance was demonstrated at $P<0.05$. Data were analysed using SPSS version 24 (IBM Corp.).

\section{Results}

\section{Participant characteristics pre-initial military training}

Participant characteristics pre-IMT appear in Table 1. Participants were on average 19 years old, were predominantly White or Black and were of a healthy BMI $\left(<25 \mathrm{~kg} / \mathrm{m}^{2}\right)$. Males were heavier and had less body fat than females $(P<0.001$ for both). Dietary intake of Ca, vitamin D and Mg did not differ between females and males ( $P>0.05$ for all comparisons). Mean

Table 1. Participant characteristics pre-military training ${ }^{\star}$ (Mean values and standard deviations; number and percentages; median values and interquartile range)

\begin{tabular}{|c|c|c|c|c|c|}
\hline & \multicolumn{2}{|c|}{ Female } & \multicolumn{2}{|c|}{ Male } & \multirow[b]{2}{*}{$P$} \\
\hline & $n$ & $\%$ & $n$ & $\%$ & \\
\hline \multicolumn{6}{|l|}{ Demographics } \\
\hline \multicolumn{6}{|l|}{ Treatment } \\
\hline Placebo & 31 & 50 & 28 & 55 & \\
\hline Ca/vitamin D & 31 & 50 & 23 & 45 & \\
\hline \multicolumn{6}{|l|}{ Age (years) } \\
\hline Mean & \multicolumn{2}{|c|}{$19 \cdot 1$} & \multicolumn{2}{|c|}{$18 \cdot 7$} & 0.119 \\
\hline SD & \multicolumn{2}{|c|}{$2 \cdot 0$} & \multicolumn{2}{|c|}{$1 \cdot 0$} & \\
\hline \multicolumn{6}{|l|}{ Race } \\
\hline White & & $69 \cdot 4$ & & $84 \cdot 3$ & \\
\hline Black & & $21 \cdot 0$ & & $15 \cdot 7$ & \\
\hline Asian & & $3 \cdot 2$ & & 0 & \\
\hline Other & & $6 \cdot 4$ & & 0 & \\
\hline \multicolumn{6}{|l|}{ BMI $\left(\mathrm{kg} / \mathrm{m}^{2}\right)$} \\
\hline Mean & \multicolumn{2}{|c|}{23.4} & \multicolumn{2}{|c|}{24.4} & 0.058 \\
\hline SD & \multicolumn{2}{|c|}{$2 \cdot 3$} & \multicolumn{2}{|c|}{2.9} & \\
\hline \multicolumn{6}{|l|}{ Height (cm) } \\
\hline Mean & \multicolumn{2}{|c|}{$162 \cdot 9$} & \multicolumn{2}{|c|}{$176 \cdot 1$} & $<0.001$ \\
\hline SD & \multicolumn{2}{|c|}{5.4} & \multicolumn{2}{|c|}{$5 \cdot 7$} & \\
\hline \multicolumn{6}{|l|}{ Weight (kg) } \\
\hline Mean & \multirow{2}{*}{\multicolumn{2}{|c|}{$\begin{array}{c}62.3 \\
6.9\end{array}$}} & \multicolumn{2}{|c|}{$75 \cdot 8$} & $<0.001$ \\
\hline SD & & & & & \\
\hline Body fat (\%) & & & & & \\
\hline Mean & & & & & $<0.001$ \\
\hline SD & & & & & \\
\hline Dietary intake $†$ & & & & & \\
\hline $\mathrm{Ca}(\mathrm{mg} / \mathrm{d})$ & & & & & \\
\hline Median & & 4.5 & & $7 \cdot 7$ & 0.192 \\
\hline IQR & & 1414 & & 1572 & \\
\hline Vitamin $D(\mu \mathrm{g} / \mathrm{d})$ & & & & & \\
\hline Median & & & & & 0.066 \\
\hline IQR & & $8 \cdot 0$ & & $9 \cdot 6$ & \\
\hline $\mathrm{Mg}(\mathrm{mg} / \mathrm{d})$ & & & & & \\
\hline Median & & & & & 0.403 \\
\hline IQR & & 412 & & 430 & \\
\hline Ca:Mg & & & & & \\
\hline Median & & & & & 0.387 \\
\hline IQR & & $4 \cdot 3$ & & 4.5 & \\
\hline Serum $\mathrm{Mg}(\mathrm{mmol} / \mathrm{l})$ & & & & & \\
\hline Mean & & & & & 0.001 \\
\hline SD & & & & & \\
\hline$<0.75(\mathrm{mmol} / \mathrm{l}, \%)$ & 22 & 35 & 9 & 18 & \\
\hline $0.75-0.95(\mathrm{mmol} / \mathrm{l}, \%)$ & 39 & 63 & 37 & 73 & \\
\hline > 95 (mmol/l, \%) & 1 & 2 & 5 & 10 & \\
\hline
\end{tabular}

EAR, estimated average requirement; IQR, interquartile range.

* Female, $n$ 62; male, $n 51$.

† EAR (Mg): $300 \mathrm{mg} / \mathrm{d}$ (females 14-18 years), $340 \mathrm{mg} / \mathrm{d}$ (males 14-18 years), $255 \mathrm{mg} /$ $\mathrm{d}$ (females $19-30$ years), $330 \mathrm{mg} / \mathrm{d}$ (males $19-30$ years). 
Ca-to-Mg intake ratios at baseline were high in both females and males compared with the optimal range of $1 \cdot 7-2 \cdot 6^{(28)}$. Approximately half of the participants met their respective EAR. Females had lower serum Mg concentrations pre-IMT compared with males $(P=0 \cdot 001)$, and a higher percentage of females (35\%) were below the current serum Mg cut-off compared with males (18\%). Univariate and multiple regression models were used to determine whether dietary Mg was associated with serum $\mathrm{Mg}$ concentrations (online Supplementary Table 1). Unadjusted models and models adjusted for energy intake while accounting for age, race and BMI were used. Dietary Mg intake was not a significant predictor of serum $\mathrm{Mg}$ in males or females pre-IMT.

Relationship between serum magnesium and indices of bone health pre-initial military training

Univariate and multiple regression models that included serum $\mathrm{Mg}$, age, race, height, weight (model 1) and iCa (model 2) for females and males pre-IMT appear in Table 2. Serum Mg concentrations were positively associated with BMC $(\beta=0.367$, $P=0.004)$ and robustness $(\beta=0.393, P=0.006)$ at the $4 \%$ site, stress-strain index of the polaris axis $(\beta=0.334, P=0.009)$ and robustness $(\beta=0.420, P=0.004)$ at the $14 \%$ site, and cortical $\operatorname{BMC}(\beta=0.309, P=0.009)$ and stress-strain index of the polaris axis $(\beta=0.314, P=0.006)$ at the $66 \%$ in females using model 2 . In males, serum $\mathrm{Mg}$ was positively associated with osteocalcin ( $\beta=0.327, P=0.023$ ) using model 2 and negatively associated with P1NP $(\mathrm{R}=-0 \cdot 298, P=0.034)$ and robustness at the $14 \%$ site ( $\beta=-0.320, P=0.047)$ using the univariate model; no significant relationships between serum $\mathrm{Mg}$ concentrations and bone parameters were observed in males in either of the multiple regression models.

The same univariate and multiple regression models that included serum $\mathrm{Mg}$, age, race, height, weight (model 1) and iCa (model 2) were used to assess the relationship between dietary $\mathrm{Mg}$ intake and bone parameters in females and males

Table 2. Relationship between serum magnesium concentration and bone parameters in females and males pre-military training

\begin{tabular}{|c|c|c|c|c|c|c|c|c|}
\hline & \multicolumn{2}{|c|}{ Univariate } & \multicolumn{3}{|c|}{ Model 1† } & \multicolumn{3}{|c|}{ Model $2 \ddagger$} \\
\hline & $R$ & $P$ & $R$ & $\beta$ & $P$ & $R$ & $\beta$ & $P$ \\
\hline \multicolumn{9}{|l|}{ Female } \\
\hline PTH & 0.053 & 0.685 & 0.353 & 0.110 & 0.435 & 0.446 & 0.064 & 0.640 \\
\hline OCN & -0.093 & 0.474 & 0.173 & -0.091 & 0.536 & 0.173 & -0.090 & 0.545 \\
\hline P1NP & -0.031 & 0.810 & 0.308 & 0.028 & 0.844 & 0.339 & 0.051 & 0.721 \\
\hline BAP & 0.108 & 0.404 & $0.448^{*}$ & -0.040 & 0.764 & $0.552^{*}$ & -0.094 & 0.461 \\
\hline CTX & 0.031 & 0.810 & $0.480^{*}$ & 0.084 & 0.524 & $0.509^{*}$ & 0.112 & 0.395 \\
\hline TRAP5b & -0.021 & 0.872 & $0.500^{*}$ & -0.091 & 0.482 & $0.506^{*}$ & -0.078 & 0.555 \\
\hline $4 \% \mathrm{BMC}$ & 0.247 & 0.072 & $0.656^{*}$ & 0.361 & 0.003 & $0.657^{*}$ & 0.367 & 0.004 \\
\hline $4 \%$ vBMD & -0.053 & 0.705 & $0.481^{*}$ & -0.040 & 0.770 & 0.483 & -0.034 & 0.810 \\
\hline $4 \% \mathrm{BSI}$ & 0.143 & 0.302 & $0.573^{*}$ & 0.231 & 0.075 & $0.575^{\star}$ & 0.238 & 0.073 \\
\hline $4 \%$ robustness & 0.298 & 0.029 & $0.507^{\star}$ & 0.407 & 0.004 & $0.514^{*}$ & 0.393 & 0.006 \\
\hline $14 \% \mathrm{BMC}$ & 0.007 & 0.957 & $0.518^{\star}$ & 0.064 & 0.634 & $0.518^{*}$ & 0.062 & 0.648 \\
\hline $14 \%$ vBMD & -0.095 & 0.493 & 0.345 & -0.093 & 0.528 & 0.356 & -0.107 & 0.476 \\
\hline $14 \%$ SSIp & 0.247 & 0.072 & $0.635^{\star}$ & 0.329 & 0.008 & $0.363^{\star}$ & 0.334 & 0.009 \\
\hline $14 \%$ robustness & 0.333 & 0.014 & $0.492^{*}$ & 0.428 & 0.003 & 0.494 & 0.420 & 0.004 \\
\hline $66 \% \mathrm{BMC}$ & 0.230 & 0.095 & $0.694^{*}$ & 0.319 & 0.006 & $0.696^{\star}$ & 0.309 & 0.009 \\
\hline $66 \%$ vBMD & -0.103 & 0.459 & 0.249 & -0.085 & 0.575 & 0.266 & -0.100 & 0.515 \\
\hline $66 \%$ SSIp & 0.217 & 0.116 & $0.719^{\star}$ & 0.310 & 0.006 & $0 \cdot 720^{*}$ & 0.314 & 0.006 \\
\hline \multicolumn{9}{|l|}{ Male } \\
\hline PTH & 0.068 & 0.635 & 0.407 & 0.110 & 0.452 & 0.417 & $0 \cdot 108$ & 0.467 \\
\hline OCN & $0.322^{*}$ & 0.021 & $0.502^{*}$ & 0.329 & 0.021 & $0.517^{*}$ & 0.327 & 0.023 \\
\hline P1NP & $-0.298^{\star}$ & 0.034 & $0.551^{*}$ & $0.178^{*}$ & 0.184 & $0.642^{*}$ & -0.179 & 0.159 \\
\hline BAP & 0.177 & 0.215 & 0.304 & 0.163 & 0.285 & 0.314 & 0.147 & 0.345 \\
\hline CTX & 0.008 & 0.955 & 0.364 & 0.027 & 0.856 & 0.407 & 0.036 & 0.812 \\
\hline TRAP5b & -0.015 & 0.616 & $0.492^{*}$ & -0.007 & 0.958 & $0.524^{\star}$ & -0.031 & 0.821 \\
\hline $4 \% \mathrm{BMC}$ & -0.139 & 0.399 & $0.620^{*}$ & -0.086 & 0.567 & $0.651^{*}$ & -0.085 & 0.576 \\
\hline $4 \%$ vBMD & 0.043 & 0.797 & 0.419 & 0.054 & 0.757 & 0.540 & 0.059 & 0.725 \\
\hline $4 \% \mathrm{BSI}$ & -0.037 & 0.825 & 0.459 & -0.004 & 0.982 & 0.540 & 0.001 & 0.993 \\
\hline $4 \%$ robustness & -0.196 & 0.231 & $0.654^{*}$ & -0.140 & 0.336 & $0.653^{*}$ & -0.136 & 0.371 \\
\hline $14 \% \mathrm{BMC}$ & $-0 \cdot 125$ & 0.449 & $0.582^{*}$ & -0.064 & 0.682 & $0 \cdot 666^{\star}$ & -0.058 & 0.698 \\
\hline $14 \%$ vBMD & 0.004 & 0.983 & 0.489 & -0.087 & 0.601 & 0.561 & -0.146 & 0.378 \\
\hline $14 \%$ SSIp & -0.287 & 0.077 & $0.773^{\star}$ & -0.225 & 0.071 & $0 \cdot 787^{\star}$ & -0.234 & 0.065 \\
\hline $14 \%$ robustness & -0.320 & 0.047 & $0.718^{*}$ & -0.267 & 0.051 & $0.719^{\star}$ & -0.272 & 0.056 \\
\hline $66 \% \mathrm{BMC}$ & -0.173 & 0.293 & $0.628^{*}$ & -0.194 & 0.198 & $0.628^{*}$ & -0.173 & 0.268 \\
\hline $66 \%$ vBMD & -0.016 & 0.923 & 0.280 & -0.101 & 0.583 & 0.460 & -0.139 & 0.434 \\
\hline $66 \%$ SSIp & -0.294 & 0.069 & $0.708^{\star}$ & -0.246 & 0.075 & $0.716^{\star}$ & -0.231 & 0.103 \\
\hline
\end{tabular}

PTH, parathyroid hormone; OCN, osteocalcin; P1NP, procollagen 1N-terminal peptide; BAP, bone alkaline phosphatase; CTX, c-telopeptide cross-links of type 1 collagen; TRAP5b, tartrate-resistant acid phosphatase 5b; BMC, bone mineral content; vBMD, volumetric bone mineral density; BSI, bone strength index; SSIp, stress-strain index of the polar axis; iCa, ionised $\mathrm{Ca}$.

$\mathrm{R}$ for the model and standardised $\beta$ coefficients and $P$-values for serum $\mathrm{Mg}$ are shown. PTH, $n 51$; bone parameters, $n 39$.

${ }^{*} P<0.05$ for the model.

† Covariates: serum Mg, age, race, height and weight.

$\ddagger$ Covariates: serum $\mathrm{Mg}$, iCa, age, race, height and weight. 
pre-military training (online Supplementary Table 2). Dietary Mg was negatively associated with PTH in females for all models (univariate $\mathrm{R}=-0.373, P=0.003$; model $1 \beta=-0.327, P=0 \cdot 011$; model $2 \beta=-0.304, P=0.014)$, but not in males, was negatively associated with robustness at the $14 \%$ site in males for most models (univariate $\mathrm{R}=-0.315, P=0 \cdot 051$; model $1 \beta=-0 \cdot 287, P=0 \cdot 031$; model $2 \beta=-0 \cdot 383, P=0 \cdot 010$ ), but not in females, and was negatively associated with P1NP, a marker of bone formation (model 1 $\beta=-0.273, P=0.043$ ), and $4 \%$ robustness (univariate $\mathrm{R}=-0.319$, $P=0.048)$ in males using one of the three models.

Females and males were separated based on the $0.75 \mathrm{mmol} / \mathrm{l}$ and $0.85 \mathrm{mmol} / 1$ serum Mg cut-offs pre-IMT, and markers of bone health were determined (online Supplementary Table 3). $\mathrm{BMC}$ at the $4 \%$ site and robustness at the 4 and $14 \%$ sites were greater $(P<0.05$ for all $)$ in females with a serum Mg concentration $>0.75$ compared with $\leq 0.75 \mathrm{mmol} / \mathrm{l}$ pre-IMT. The observed differences in females pre-IMT were not observed when the serum $\mathrm{Mg}$ cut-off was increased to $0.85 \mathrm{mmol} / \mathrm{l}$. There were no differences in any of the bone parameters in males pre-IMT regardless of the serum Mg cut-off.

\section{Change in body composition, dietary intake and biochemical measures during initial military training}

Changes in body composition, dietary intake and biochemical measures from pre- to post-IMT appear in Table 3. Females lost more body fat than males $(-5.02 \pm 2.94$ and $-3.12 \pm 3.63 \mathrm{~kg}$, $P=0.002)$. Females and males in the $\mathrm{Ca} /$ vitamin $\mathrm{D}$ group consumed approximately more Ca and vitamin D during IMT than those in the placebo group. Dietary $\mathrm{Mg}$ did not change from pre- to post-IMT. Ca-to-Mg ratios increased in the $\mathrm{Ca} /$ vitamin D group $(3.32 \pm 1.85)$ compared with those in the placebo group $(-0.16 \pm 1 \cdot 14 ; P<0.001)$, and there was a greater increase in females $(1.97 \pm 2.34)$ compared with males $(0 \cdot 94 \pm 2 \cdot 17 ; P=0 \cdot 003)$.

Sex and group differences were observed for the change in serum Mg, osteocalcin, BAP and TRAP5b with training. Serum $\mathrm{Mg}$ increased during IMT in females compared with males $(0.06 \pm 0.08$ and $-0.02 \pm 0.10 \mathrm{mmol} / 1, P<0.001)$. Osteocalcin $(-1.97 \pm 2.78$ and $-3.03 \pm 3.39 \mathrm{ng} / \mathrm{l})$, BAP $(-0.76 \pm 2.78$ and $-7.03 \pm 7.56 \mathrm{U} / \mathrm{l})$, CTX $(-0.11 \pm 0.28$ and $-0.33 \pm 0.33 \mathrm{ng} / \mathrm{ml})$ and TRAP5b $(-0.02 \pm 0.97$ and $-0.31 \pm 0.91 \mathrm{U} / \mathrm{l})$ declined in females and males during IMT, with a greater decline in males compared with females $(P<0.05$ for all comparisons).

Serum Mg increased during IMT in those consuming $\mathrm{Ca} /$ vitamin D compared with placebo $(0.046 \pm 0.09$ and $0.001 \pm 0.11 \mathrm{mmol} / \mathrm{l}, P=0.015)$. Osteocalcin $(-3.34 \pm 3.45$ and $-1.63 \pm 2.51 \mathrm{ng} / \mathrm{l}), \operatorname{BAP}(-5.74 \pm 8.18$ and $-1.62 \pm 6.90 \mathrm{U} / \mathrm{l})$ and TRAP5b $(-0.52 \pm 0.88$ and $0.23 \pm 0.88 \mathrm{U} / \mathrm{l})$ decreased in those consuming $\mathrm{Ca} /$ vitamin $\mathrm{D}$ compared with placebo ( $P<0.05$ for all comparisons).

\section{Relationship between change in serum magnesium} and change in indices of bone turnover during initial military training

Univariate and multiple regression models were used to determine if changes in serum Mg during IMT were associated with changes in bone turnover markers (online Supplementary
Table 4). No significant relationships were observed in females. In males, change in serum $\mathrm{Mg}$ was positively associated with change in TRAP5b using model $1(\beta=0.313, P=0.021)$ and model $2(\beta=0.333, P=0.014)$.

\section{Discussion}

The major findings from the current study were (1) dietary Mg intakes were below the EAR and hypomagnesemia was observed in a large proportion of females and males prior to and during IMT, (2) serum Mg was associated with parameters of bone health in females, but not in males and (3) Ca/vitamin D supplementation during IMT increased serum Mg compared with placebo. These findings indicate that $\mathrm{Mg}$ may be a nutrient of concern for military recruits, which may be particularly relevant given the increased incidence of tibial stress fractures during military training, as compared with other times in a service member's career.

Median dietary Mg intakes were below recommendations pre(Table 1) and post-IMT (data not shown), respectively. The finding that approximately half of males and females did not meet the EAR for Mg pre- or post-IMT is consistent with the NHANES 2007-2010 data used by the 2015 Dietary Guidelines Advisory Committee ${ }^{(3)}$. However, the current EAR was based on a study in 16 men and 18 women who consumed a selfselected diet $^{(29)}$. Since that time, $\mathrm{Mg}$ balance data from twentyseven studies were compiled and an EAR of $165 \mathrm{mg} / \mathrm{d}$ (RDA of $250 \mathrm{mg} / \mathrm{d}$ ), regardless of sex and age, was suggested ${ }^{(30)}$. Using these criteria, $16 \%$ and $7 \%$ of females and $8 \%$ and $4 \%$ of males were below the EAR pre- and post-IMT, respectively. However, it should be noted that the values above are for approximately $70 \mathrm{~kg}$ individuals, vary with body weight, and do not consider the physical demands of military training. Regardless, choosing foods rich in $\mathrm{Mg}$, including whole grains, nuts and seeds, and vegetables, remains an important consideration.

The current lower cut-off for serum $\mathrm{Mg}(0.75 \mathrm{mmol} / \mathrm{l})$ was developed based on serum Mg concentrations from a representative national sample of the US population between 1971 and $1974^{(4)}$. Based on these criteria, females were twice as likely (35\%) to be below the cut-off pre-IMT compared with males (18\%) (Table 1). Increased risk for conditions associated with low Mg intake or hypomagnesemia, such as hypertension, CVD, type 2 diabetes and osteoporosis, have been observed with serum $\mathrm{Mg}$ concentrations within the current reference interval. Thus, current evidence has led some to suggest that the lower cut-off could be increased to $0.85 \mathrm{mmol} / \mathrm{l}^{(5)}$. If the lower cut-off were to increase to $0.85 \mathrm{mmol} / 1$, the percentage of females ( $81 \%$ ) and males (49\%) below the cut-off in the current study would more than double. Interestingly, BMC at the $4 \%$ site and total and cortical cross-sectional area at the $4 \%$ and $14 \%$ sites were elevated in females with serum $\mathrm{Mg}>0.75 \mathrm{mmol} / \mathrm{l}$ compared with $\leq 0.75 \mathrm{mmol} / \mathrm{l}$, but not when the cut-off was increased to $0.85 \mathrm{mmol} / \mathrm{l}$. Although these findings are not causative, serum Mg was a significant predictor of each of these variables in multiple regression models, suggesting that a lower cut-off of $0.75 \mathrm{mmol} / \mathrm{l}$ may be associated with lower bone mineral status. 
Table 3. Change in body composition, dietary intake and biochemical measures pre- to post-military training* (Mean values and standard deviations)

Demographics

$\mathrm{BMl}\left(\mathrm{kg} / \mathrm{m}^{2}\right)$

Pre

Post

$\Delta$

Weight (kg)

Pre

Post
$\Delta$

Body fat (\%)

Pre

Post

$\Delta$

Dietary intake

$\mathrm{Ca}(\mathrm{mg} / \mathrm{d})$

Post

$\Delta$

Vitamin D $(\mu \mathrm{g} / \mathrm{d})$

Pre

Post

$\Delta$

$\mathrm{Mg}(\mathrm{mg} / \mathrm{d})$

Pre

Post

Ca:Mg

Pre

Post

$\Delta$

PTH (pg/ml)

Pre
Post
$\Delta$
iCa $(n m o l / l)$
Pre
Post

Biochemical measures

$\Delta$

25- $(\mathrm{OH}) \mathrm{D}_{3}(\mathrm{ng} / \mathrm{ml})$

Pre

$\stackrel{\Delta}{1,25-(\mathrm{OH})_{2} \mathrm{D}_{3}(\mathrm{ng} / \mathrm{ml})}$

Pre

Post

$\Delta$

$\mathrm{Mg}(\mathrm{mmol} / \mathrm{l})$

Pre

$\Delta$

$\stackrel{\Delta}{\text { OCN }(n g / m l)}$

Pre

Post

$\Delta$

P1NP (pg/ml)

Pre
Post

$\stackrel{\Delta}{\operatorname{BAP}(U / I)}$

Pre

Post

$23 \cdot 6$

23.6
-0.54

$65 \cdot 2$

63.8
-1.42

$-1.42$

$23.6 \quad 4$

$18 \cdot 0$
$-5 \cdot 61$

98

1192.1

206.6

$5 \cdot 3$
$7 \cdot 1$

$1 \cdot 8$

$277 \cdot 1$

333.1

$56 \cdot 0$

\subsection{3}

3.90

0.27

$33.0 \quad 13$

33.3

0.33

$1.20 \quad 0.03$

$1.20 \quad 0.04$

0.0006

$30 \cdot 1$

$-1.42$

84.6
81.7

$81 \cdot 7$
$-2 \cdot 29$

0.76

0.81

0.05

$9 \cdot 5$

8.0

$-1.45$

$34 \cdot 3$

32.5

$-1.84$

$26 \cdot 2$
$27 \cdot 9$

27.9
1.69

\begin{tabular}{|c|c|c|c|c|c|c|c|c|c|c|}
\hline \multicolumn{4}{|c|}{ Female } & \multicolumn{4}{|c|}{ Male } & & & \\
\hline \multicolumn{2}{|c|}{ Placebo } & \multicolumn{2}{|c|}{ Ca/vitamin D } & \multicolumn{2}{|c|}{ Placebo } & \multicolumn{2}{|c|}{ Ca/vitamin D } & \multicolumn{3}{|c|}{$P$} \\
\hline Mean & SD & Mean & SD & Mean & SD & Mean & SD & Sex & Group & Sex-by-group \\
\hline
\end{tabular}

$\begin{array}{ll}1.5 & 22.7 \\ 1.24 & -0.05\end{array}$

$2 \cdot 0$

24.0

$-0.56$

3.0

$\begin{array}{ll}3.2 & 24.1 \\ 1 \cdot 3 & 24.1\end{array}$

$1.32-0.06$

$-0.06$

$6.3 \quad 59.4$

$5.1 \quad 59.3$

$3.40 \quad-0.15$

$6.3 \quad 74.5$

$5.4 \quad 72.7$

$\begin{array}{ll}5.4 & 72 \cdot 7 \\ 2.84 & -1.74\end{array}$

$10 \cdot 1 \quad 77.5$

$7 \cdot 7$

$\begin{array}{ll}7.7 & 77.2 \\ 3.99 & -0.23\end{array}$

$\begin{array}{rr}3.7 & 11.5 \\ 3.3 & 8.2\end{array}$

$\begin{array}{ll}3.5 & 15.9 \\ 3.08 & -4.42\end{array}$

$2.72-3.36$

$3.9 \quad 12.6$

1.9

9.7

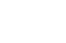

$\begin{array}{llll}492.5 & 1246.3 & 696.9 & 1278.1\end{array}$

$\begin{array}{ll}562.0 & 2198 \cdot 3\end{array}$

$701.6 \quad 952.0$

$662.9 \quad 973.6$

$\begin{array}{ll}678.3 & 1250 \cdot 9 \\ 428.6 & 2100 \cdot 1\end{array}$

$\begin{array}{rr}428.6 & 2100 \cdot \\ 737.2 & 849 \cdot 2\end{array}$

$3.4 \quad 7 \cdot 2$

872 .

$-304.5$

$5 \cdot 2 \quad 34.8$

$5.0 \quad 7.9$

$5.5 \quad 5.4$

$5 \cdot 1$

$3 \cdot 5$

7.9

$6.2-2.6$

$6 \cdot 0$

$32 \cdot 6$

$\begin{array}{llll}133.1 & 355.6 & 180 \cdot 7 & 332.3\end{array}$

$\begin{array}{ll}114.5 & 351.2\end{array}$

$125 \cdot 6$
$179 \cdot 3$

$327 \cdot 3$

$134 \cdot 1 \quad 350 \cdot 2$

109.5

$149 \cdot 0$

$360 \cdot 6$

10.3

$0.95 \quad 3.58$

1.08

3.82

1.06

1.06

3.70

$\begin{array}{ll}0.61 & 6.57 \\ 1.24 & 2.87\end{array}$

$2.12-0.65$

1.24

\section{9}

$2 \cdot 3$

$\begin{array}{ll}- & - \\ - & -\end{array}$

11.3

$\begin{array}{rrr}11.3 & - & - \\ 9.4 & - & -\end{array}$

$\begin{array}{llll}6.0 & - & - & - \\ 3.9 & - & - & -\end{array}$

$\begin{array}{llll}3.74 & 0.002 & 0.166 & 0.594\end{array}$

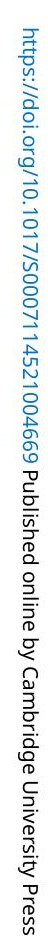


Table 3. (Continued)

\begin{tabular}{|c|c|c|c|c|c|c|c|c|c|c|c|}
\hline & \multicolumn{4}{|c|}{ Female } & \multicolumn{4}{|c|}{ Male } & & & \\
\hline & \multicolumn{2}{|c|}{ Placebo } & \multicolumn{2}{|c|}{ Ca/vitamin D } & \multicolumn{2}{|c|}{ Placebo } & \multicolumn{2}{|c|}{$\mathrm{Ca} /$ vitamin D } & \multicolumn{3}{|c|}{$P$} \\
\hline & Mean & SD & Mean & SD & Mean & SD & Mean & SD & Sex & Group & Sex-by-group \\
\hline \multicolumn{12}{|c|}{ CTX $(\mathrm{ng} / \mathrm{ml})$} \\
\hline Pre & 0.82 & 0.33 & 0.77 & 0.27 & $1 \cdot 19$ & 0.37 & $1 \cdot 14$ & 0.29 & - & - & - \\
\hline Post & 0.74 & 0.23 & 0.63 & 0.22 & 0.85 & 0.31 & 0.82 & 0.33 & - & - & - \\
\hline $\begin{array}{l}\text { Change } \\
\text { TRAP5 }\end{array}$ & -0.08 & 0.27 & -0.14 & 0.29 & -0.34 & 0.35 & -0.32 & 0.31 & $<0.001$ & 0.701 & 0.489 \\
\hline Pre & 3.58 & 0.97 & 3.72 & 0.91 & 4.30 & 1.70 & 4.02 & 1.19 & - & - & - \\
\hline Post & 4.08 & 0.96 & 3.26 & 0.91 & 4.22 & 1.37 & 3.41 & 0.77 & - & - & - \\
\hline$\Delta$ & 0.50 & 0.81 & -0.46 & 0.89 & -0.07 & 0.87 & -0.61 & 0.88 & 0.029 & $<0.001$ & 0.203 \\
\hline
\end{tabular}

PTH, parathyroid hormone; iCa, ionised Ca; 25- $(\mathrm{OH}) \mathrm{D}_{3}, 25$-hydroxyvitamin $\mathrm{D} ; 1,25-(\mathrm{OH})_{2} \mathrm{D}_{3}, 1,25$-dihydroxyvitamin $\mathrm{D}$; OCN, osteocalcin; $\mathrm{P} 1 \mathrm{NP}$, procollagen $1 \mathrm{~N}$-terminal peptide; BAP, bone alkaline phosphatase; CTX, c-telopeptide cross-links of type 1 collagen; TRAP5b, tartrate-resistant acid phosphatase $5 \mathrm{~b}$.

${ }^{*}$ Female placebo, $n$ 31; female Ca/vitamin $\mathrm{D}, n$ 31; male placebo, $n$ 28; male Ca/vitamin $\mathrm{D}, n 23$.

Exercise is known to redistribute $\mathrm{Mg}$ in the body ${ }^{(16)}$. In general, short-term, high-intensity exercise results in a transient increase of about $5-15 \%$, while prolonged endurance exercise reduces circulating concentrations of $\mathrm{Mg}$ (reviewed in ${ }^{(16,31)}$ ). In the current study, the serum Mg response to military training varied based on sex. Serum Mg increased with military training in females, but not in males. The source of the increase in serum $\mathrm{Mg}$ in females is unclear; however, exercise-induced increases in serum $\mathrm{Mg}$ concentration may reflect $\mathrm{Mg}$ being pulled from the bone surface to help maintain serum Mg concentrations ${ }^{(2)}$. Rude and colleagues performed a series of studies that induced Mg deficiency by feeding rats $0.4 \%, 10 \%, 25 \%$ and $50 \%$ of the $\mathrm{Mg}$ requirement ${ }^{(9-13)}$. Female rats fed even the most modest restriction ( $50 \%$ of the $\mathrm{Mg}$ requirement) had reduced bone $\mathrm{Mg}$ concentrations, trabecular bone volume and trabecular $\mathrm{BMC}$ at the distal femur compared with controls ${ }^{(9)}$. Importantly, the detrimental effects of $\mathrm{Mg}$ restriction on bone health were observed in the absence of a decline in serum $\mathrm{Mg}$ concentrations $^{(9)}$. In the current study, females had a higher prevalence of hypomagnesemia compared with males and serum $\mathrm{Mg}$ in females was positively associated with bone parameters pre-IMT. Despite these findings, the increase in serum $\mathrm{Mg}$ in females during IMT could not be explained by an increase in bone turnover markers. Alternative explanations for the increase in serum Mg post-IMT include shifts in plasma volume ${ }^{(32,33)}$, increased muscle breakdown and release of $\mathrm{Mg}$ into circulation, as approximately one-third of total body $\mathrm{Mg}$ is found in skeletal muscle ${ }^{(1)}$, and/or reduced Mg utilisation in females compared with males.

Serum Mg increased during IMT in those consuming $\mathrm{Ca} /$ vitamin D compared with placebo, but like the increase in serum Mg that occurred in females during IMT, could not be explained by an increase in bone turnover markers. Previous studies have demonstrated direct effects of vitamin D on intestinal $\mathrm{Mg}$ absorption ${ }^{(18)}$ and/or the modulation of PTH by $\mathrm{Mg}$, and an indirect increase in $\mathrm{Mg}$ absorption through 1,25-dihydroxyvitamin D synthesis. Either mechanism would be consistent with in vitro and human data that demonstrate that reductions in $\mathrm{Mg}$ enhance PTH secretion, whereas increased Mg inhibits PTH secretion ${ }^{(34,35)}$. Rats consuming a diet containing $50 \%$ of the $\mathrm{Mg}$ requirement had reduced serum $\mathrm{Ca}$ and 1,25-dihydroxyvitamin D and increased PTH concentrations and osteoclast numbers ${ }^{(9)}$. In the current study, females had lower serum Mg and increased PTH concentrations compared with males pre-IMT; however, it should be noted that serum Mg was not associated with PTH in the current study.

This study has several limitations. First, it was a secondary analysis of a randomised, double-blind, placebo-controlled trial examining the effects of $\mathrm{Ca} /$ vitamin $\mathrm{D}$ supplementation on bone health in military recruits and was therefore not designed to specifically look at the outcomes reported. Secondly, serum $\mathrm{Mg}$ as a measure of total body Mg status has known limitations ${ }^{(1)}$. And lastly, the numerous study outcomes increase the risk of making a type I error. Strengths of the current study include the ability to relate serum $\mathrm{Mg}$ concentrations to indicators of bone health using both imaging (peripheral quantitative computed tomography) and biochemical markers in apparently healthy females and males.

In conclusion, serum $\mathrm{Mg}$ was positively associated with some peripheral quantitative computed tomography indices of bone health in healthy young females prior to military training. Serum Mg increased during military training in females, but not in males. These findings indicate that $\mathrm{Mg}$ may be a nutrient of concern for female military recruits as Mg may be mobilised from bone to increase circulating concentrations during training. Further research is required to determine dietary Mg requirements during military or athletic training.

\section{Acknowledgements}

Approved for public release; distribution is unlimited. The opinions or assertions contained herein are the private views of the authors and are not to be construed as official or as reflecting the views of the Army or the Department of Defense. Any citations or commercial organisations and trade names in this report do not constitute an official Department of the Army endorsement of approval of the products or services of these organisations.

Supported in part by the US Army Medical Research and Materiel Command and appointment to the US Army Research Institute of Environmental Medicine administered by the Oak Ridge Institute for Science and Education (to SRH, AMK, ATN and BJN) through an interagency agreement between the US Department of Energy and the US Army Medical Research and Materiel Command. 
S. R. H., E. G-S. and J. P. M. designed the study; S. R. H., E. G-S., A. M. K., A. T. N., B. J. A. and J. P. M. executed the study; S. R. H. analysed the data and wrote the manuscript. S. R. H. had primary responsibility for final content and all authors read and approved the final manuscript.

None of the authors have conflicts of interest to report.

\section{Supplementary material}

For supplementary material/s referred to in this article, please visit https://doi.org/10.1017/S0007114521004669

\section{References}

1. Elin RJ (1994) Magnesium: the fifth but forgotten electrolyte. Am J Clin Pathol 102, 616-622.

2. Alfrey AC \& Miller NL (1973) Bone magnesium pools in uremia. J Clin Invest 52, 3019-3027.

3. USDHHS (2015) Scientific report of the 2015 Dietary Guidelines Advisory Committee: US Department of Health and Human Services. https://health.gov/dietaryguidelines/2015-scientificreport/ (accessed March 2019).

4. Lowenstein FW \& Stanton MF (1986) Serum magnesium levels in the United States, 1971-1974. J Am Coll Nutr 5, 399-414.

5. Costello RB, Elin RJ, Rosanoff A, et al. (2016) Perspective: the case for an evidence-based reference interval for serum magnesium: the time has come. Adv Nutr 7, 977-993.

6. Volpe SL (2013) Magnesium in disease prevention and overall health. Adv Nutr 4, 378S-383S.

7. New SA, Robins SP, Campbell MK, et al. (2000) Dietary influences on bone mass and bone metabolism: further evidence of a positive link between fruit and vegetable consumption and bone health? Am J Clin Nutr 71, 142-151.

8. Tucker KL, Hannan MT, Chen H, et al. (1999) Potassium, magnesium, and fruit and vegetable intakes are associated with greater bone mineral density in elderly men and women. $A m J$ Clin Nutr 69, 727-736.

9. Rude RK, Gruber HE, Norton HJ, et al. (2006) Reduction of dietary magnesium by only $50 \%$ in the rat disrupts bone and mineral metabolism. Osteoporos Int 17, 1022-1032.

10. Rude RK, Gruber HE, Norton HJ, et al. (2005) Dietary magnesium reduction to $25 \%$ of nutrient requirement disrupts bone and mineral metabolism in the rat. Bone 37, 211-219.

11. Rude RK, Gruber HE, Norton HJ, et al. (2004) Bone loss induced by dietary magnesium reduction to $10 \%$ of the nutrient requirement in rats is associated with increased release of substance $\mathrm{P}$ and tumor necrosis factor-alpha. J Nutr 134, 79-85.

12. Rude RK, Kirchen ME, Gruber HE, et al. (1999) Magnesium deficiency-induced osteoporosis in the rat: uncoupling of bone formation and bone resorption. Magnes Res 12, $257-267$.

13. Rude RK, Singer FR \& Gruber HE (2009) Skeletal and hormonal effects of magnesium deficiency. J Am Coll Nutr 28, 131-141.

14. Jones BH, Thacker SB, Gilchrist J, et al. (2002) Prevention of lower extremity stress fractures in athletes and soldiers: a systematic review. Epidemiol Rev 24, 228-247.

15. Cowan JA (2002) Structural and catalytic chemistry of magnesium-dependent enzymes. Biometals 15, 225-235.

16. Nielsen FH \& Lukaski HC (2006) Update on the relationship between magnesium and exercise. Magnes Res 19, 180-189.
17. Gaffney-Stomberg E, Nakayama AT, Guerriere KI, et al. (2019) Calcium and vitamin D supplementation and bone health in Marine recruits: effect of season. Bone 123, 224-233.

18. Levine BS, Brautbar N, Walling MW, et al. (1980) Effects of vitamin $\mathrm{D}$ and diet magnesium on magnesium metabolism. Am J Physiol 239, E515-23.

19. Lappe J, Cullen D, Haynatzki G, et al. (2008) Calcium and vitamin D supplementation decreases incidence of stress fractures in female navy recruits.J Bone Miner Res 23, 741-749.

20. Jackson AS \& Pollock ML (1978) Generalized equations for predicting body density of men. Br J Nutr $\mathbf{4 0}, 497-504$.

21. Jackson AS, Pollock ML \& Ward A (1980) Generalized equations for predicting body density of women. Med Sci Sports Exerc 12, 175-181.

22. Lutz LJ, Nakayama AT, Karl JP, et al. (2019) Serum and erythrocyte biomarkers of nutrient status correlate with short-term A-carotene, B-carotene, folate, and vegetable intakes estimated by food frequency questionnaire in military recruits. $J$ Am Coll Nutr 38, 171-178.

23. Pasiakos SM, Karl JP, Lutz LJ, et al. (2012) Cardiometabolic risk in US Army recruits and the effects of basic combat training. PLOS ONE 7, e31222.

24. Gaffney-Stomberg E, Lutz LJ, Rood JC, et al. (2014) Calcium and vitamin D supplementation maintains parathyroid hormone and improves bone density during initial military training: a randomized, double-blind, placebo controlled trial. Bone 68, 46-56.

25. Kontulainen S, Liu D, Manske S, et al. (2007) Analyzing cortical bone cross-sectional geometry by peripheral QCT: comparison with bone histomorphometry. J Clin Densitom 10, 86-92.

26. Kontulainen SA, Johnston JD, Liu D, et al. (2008) Strength indices from PQCT imaging predict up to $85 \%$ of variance in bone failure properties at tibial epiphysis and diaphysis. J Musculoskelet Neuronal Interact 8, 401-409.

27. Jepsen KJ, Centi A, Duarte GF, et al. (2011) Biological constraints that limit compensation of a common skeletal trait variant lead to inequivalence of tibial function among healthy young adults. J Bone Miner Res 26, 2872-2885.

28. Costello RB, Rosanoff A, Dai Q, et al. (2021) Perspective: characterization of dietary supplements containing calcium and magnesium and their respective ratio-is a rising ratio a cause for concern? Adv Nutr 12, 291-297.

29. Lakshmanan FL, Rao RB, Kim WW, et al. (1984) Magnesium intakes, balances, and blood levels of adults consuming selfselected diets. Am J Clin Nutr 40, 1380-1389.

30. Hunt CD \& Johnson LK (2006) Magnesium requirements: new estimations for men and women by cross-sectional statistical analyses of metabolic magnesium balance data. Am J Clin Nutr 84, 843-852.

31. Bohl CH \& Volpe SL (2002) Magnesium and exercise. Crit Rev Food Sci Nutr 42, 533-563.

32. Joborn H, Akerstrom G \& Ljunghall S (1985) Effects of exogenous catecholamines and exercise on plasma magnesium concentrations. Clin Endocrinol 23, 219-226.

33. Cordova A (1992) Changes on plasmatic and erythrocytic magnesium levels after high-intensity exercises in men. Physiol Behav 52, 819-821.

34. Sherwood LM, Herrman I \& Bassett CA (1970) Parathyroid hormone secretion in vitro: regulation by calcium and magnesium ions. Nature 225, 1056-1058.

35. Ferment O, Garnier PE \& Touitou Y (1987) Comparison of the feedback effect of magnesium and calcium on parathyroid hormone secretion in man. J Endocrinol 113, 117-122. 